\title{
Effect of increasing iron supplementation on blood lipids in rats $\uparrow$
}

\author{
Paul Whittaker* and Ronald F. Chanderbhan \\ Center for Food Safety and Applied Nutrition, Food and Drug Administration, 200 C Street S.W., \\ HFS-236, Washington, DC 20204, USA
}

(Received 23 November 2000 - Revised 11 June 2001 - Accepted 2 July 2001)

\begin{abstract}
The effects of increasing levels of Fe on serum fatty acids, cholesterol, triacylglycerol, liver and heart were examined in male Sprague-Dawley rats fed either Fe-deficient or carbonyl Fesupplemented diets with 35 (control), 350, 3500 and $20000 \mu \mathrm{g} \mathrm{Fe} / \mathrm{g}$ for 12 weeks. As intake of Fe increased, serum total cholesterol increased from $2.0 \mathrm{mmol} / \mathrm{l}$ in controls to $5.2 \mathrm{mmol} / \mathrm{l}$ at the highest level of Fe. Also, the total serum phospholipid fatty acids increased from $609 \mathrm{mg} / \mathrm{dl}$ in controls to $1292 \mathrm{mg} / \mathrm{l}$ at the highest level of Fe. Except for the highest dose of Fe, the ratio of saturated to unsaturated phospholipid fatty acids increased from $1 \cdot 2$ to $1 \cdot 7$. The serum total free fatty acid levels remained constant among all groups with a range from 162 to $228 \mathrm{mg} / \mathrm{l}$, while a ratio of 0.6 to 0.8 for saturated to unsaturated fatty acids was maintained. A dose-related increase in liver non-haem Fe from 18 to $3500 \mu \mathrm{g} / \mathrm{g}$ correlated with increases in lipid peroxidation $(r$ 0.87 ), measured by the lipid-conjugated diene assay. Oxidative changes in the liver may have resulted in alterations in sterol synthesis, leading to increased serum cholesterol levels with increases in serum phospholipids and changes in the ratios of their saturated to unsaturated fatty acids. Animals with heart damage showed myocardial degeneration and cardiomyopathy with haemosiderin in interstitial macrophages or myocardial fibres and, when these were coupled with the findings of increased non-haem $\mathrm{Fe}$ in the heart and lipid peroxidation in the liver, suggested that oxidative stress is involved in the pathogenesis of the lesions.
\end{abstract}

Iron: Lipids: Lipid peroxidation: Cardiotoxicity: Rats

There is substantial evidence implicating Fe-catalysed reactive oxygen species in several diseases including atherosclerosis (Witztum, 1994), cancer (Stevens et al. 1994) and Fe overload (Burkitt \& Mason, 1991). Schwartz et al. (1991) suggested that oxidative modification of LDL played a role in human atherosclerosis. Williams et al. (1991) reported that excess $\mathrm{Fe}$ enhanced the oxidative modification of LDL-cholesterol contributing to atherogenesis and promoted post-ischaemic myocardial injury by increasing the susceptibility of the heart to oxygen reperfusion damage. Subsequently, Smith et al. (1992) reported that mature atherosclerotic lesions contained detectable Fe that could promote lipid peroxidation. The mechanisms of metal ion-dependent oxidation of LDL in the presence of superoxide $\left(\mathrm{O}_{2}{ }^{--}\right)$was examined by Lynch \& Frei (1993). When LDL was exposed to hypoxanthine and xanthine oxidase with and without added $\mathrm{Fe}^{3+}$-citrate, they observed that oxidation was dependent upon $\mathrm{O}_{2}{ }^{--}$and that the system generated hydroxyl radicals $\left(\mathrm{HO}^{\circ}\right)$.
In a study involving eleven countries with more than 1100 subjects over 40 years of age, Lauffer (1991) observed that there was a direct correlation between hepatic Fe, serum cholesterol and coronary heart disease mortality. This suggested a possible synergistic effect of Fe stores with other cardiovascular risk factors. Epidemiological observations have shown that high Fe levels are associated with an increased risk of myocardial infarction in men (Salonen et al. 1992), and it was suggested that Fe overload could elevate the risk of acute myocardial infarction by promoting the oxidation of LDL-cholesterol. A strong association was found between high serum ferritin concentrations and the risk for acute myocardial infarction. Since this report, several studies have been published using serum ferritin, serum Fe, total Fe-binding capacity (TIBC), or transferrin saturation as the measure of Fe status (Baer et al. 1994; Liao et al. 1994; Magnusson et al. 1994; Sempos et al. 1994; Reunanen et al. 1995), with inconsistent results. Ascherio et al. (1994) reported that haem Fe rather than total Fe

\footnotetext{
Abbreviations: BHT, butylated hydroxytoluene; TIBC, total iron-binding capacity.

* Corresponding author: Dr Paul Whittaker, fax +1 202260 7036, email paul.whittaker@cfsan.fda.gov

$\uparrow$ The studies reported herein were conducted according to the principles set forth in the Guide for the Care and Use of Laboratory Animals, Institute of Laboratory Animal Resources, National Research Council, National Academy Press, Washington, DC, 1996. The mention of trade names, commercial products, or organizations does not imply endorsement by the US Food and Drug Administration.
} 
consumption was correlated directly with coronary disease risk among men. Other studies have shown that serum ferritin was the strongest indicator of the presence and progression of carotid artery disease (Kiechl et al. 1994, 1997). In a study of an elderly Dutch population, elevated serum ferritin concentrations were associated with increased risk of myocardial infarction (Klipstein-Grobusch et al. 1999). The association was most evident in current or former smokers and in subjects with diabetes, raising the question of whether ferritin may adversely affect ischaemic heart disease risk in the presence of other risk factors. It may be possible that these factors interact with elevated body Fe stores and may accelerate atherogenesis by stimulating the oxidation of LDL. Rasmussen et al. (2001) recently reported that increased Fe stores may play a role in the development of $\mathrm{CHD}$ by increasing lipoprotein oxidation. In a prospective study using a case-cohort design of a population from the Atherosclerosis Risk in Communities (ARIC) study, they found that individuals carrying the haemochromatosis gene (HFE) C282Y mutation may be at increased risk of CHD.

The present study was designed to determine whether alterations in serum lipids occur in rats fed Fe-deficient or Fe-supplemented diets and the relationship to lipid peroxidation.

\section{Materials and methods}

\section{Animals and diets}

Male weanling Sprague-Dawley rats (Blue Spruce Farms, Inc., Altamont, NY, USA) were individually housed in stainless steel cages and maintained in a temperature- and light-controlled environment. Four groups of rats were fed AIN-76A diets (Dyets, Inc., Bethlehem, PA, USA) supplemented with carbonyl Fe (ISP Technologies, Inc., Wayne, NJ, USA). No Fe was added to the diet of the fifth group. The AIN-76A diet (without added Fe) contained $(\mathrm{g} / \mathrm{kg})$ casein 200.0, DL-methionine $3 \cdot 0$, cornstarch $150 \cdot 0$, glucose 500.0, fibre Celufil 50.0, AIN-76 mineral mix (without $\mathrm{Fe}$ ) 35.0 and AIN-76A vitamin mix 10.0 with $50.0 \mathrm{mg}$ menadione $/ \mathrm{kg}$ and $2.0 \mathrm{~g}$ choline bitartrate $/ \mathrm{kg}$. The Fe-deficient group (4 $\mu \mathrm{g} \mathrm{Fe} / \mathrm{g}$ ) received no carbonyl $\mathrm{Fe}$ added to the diet and the control-group diet contained $35 \mu \mathrm{g}$ $\mathrm{Fe} / \mathrm{g}$. Animals in the other three groups received 350, 3500 or $20000 \mu \mathrm{g} \mathrm{Fe} / \mathrm{g}$ diet (Table 1).

The rats were initially divided into five groups of approximately equal mean body weight and were given free access to food and distilled, deionized water for 12 weeks.

Table 1. Diets given to rats for 12 weeks

\begin{tabular}{lcc}
\hline Group & $\begin{array}{c}\text { Carbonyl iron } \\
\text { dose }(\mu \mathrm{g} \mathrm{Fe} / \mathrm{g})\end{array}$ & Number of rats \\
\hline 1 & $0^{*}$ & 9 \\
2 & $35 \dagger$ & 10 \\
3 & 350 & 10 \\
4 & 3500 & 8 \\
5 & 20000 & 10 \\
\hline${ }^{*}$ Fe-deficient diet. & \\
† Control diet.
\end{tabular}

At the end of the study, the rats were anaesthetized by intramuscular injection of $5 \mathrm{mg}$ ketamine hydrochloride (Ketaset, Bristol Laboratories, Syracuse, NY, USA) per $100 \mathrm{~g}$ body weight, and decapitated. A complete necropsy was performed on each animal and tissues were fixed in $10 \%$ neutral buffered formalin. Tissue specimens were then trimmed, processed through ascending ethanol series and toluene, embedded in paraffin and sectioned at $7 \mu \mathrm{m}$. One set of tissues was stained with haematoxylin and eosin (H\&E) and one set with Perl's Prussian blue for Fe, which involves colourless potassium ferrocyanide reacting with ferric ions to create an insoluble blue ferric ferrocyanide (Thompson \& Hunt, 1966; Luna, 1968). There was special emphasis on the liver and heart tissues for tissue weights, non-haem Fe and histopathology. The non-haem Fe content was determined by the method of Whittaker et al. (1996a). Other portions of the liver were processed as described further.

\section{Lipid extraction and analysis}

For lipid analysis, $0.4 \mathrm{ml}$ aliquots of serum were diluted with $0.6 \mathrm{ml}$ normal saline $(0.9 \%)$ and extracted in $20 \mathrm{ml}$ chloroform:methanol, according to the method of Folch et al. (1957). Prior to the separation of the solvent phases of the lipid extract with $0.05 \%$ calcium chloride solution, $200 \mu \mathrm{g}$ of both ultra-pure heptadecanoic acid and L- $\alpha-$ phosphatidylcholine were added to each sample. Diheptadecanoyl was utilized to correct for losses from the extraction, derivatization and chromatographic procedures. Major lipid classes were separated by silicic acid TLC in a solvent system of hexane/ethyl ether/acetic acid (80:18:2, v/ $\mathrm{v} / \mathrm{v})$. Lipid bands were visualized with Rhodamine $6 \mathrm{G}$ and identified by comparison with authentic standards spotted in channels on either side of the same chromatoplate. Areas corresponding to phospholipids and free fatty acids were individually scraped into screw-cap tubes. Both lipid fractions were quantitatively derivatized with $15 \%$ boron trifluoride dissolved in methanol for $2 \mathrm{~h}$ at $70^{\circ} \mathrm{C}$, with tubes being vortexed every $15 \mathrm{~min}$ according to the procedure of Morrison \& Smith (1964).

Fatty acid methyl esters were determined using a Hewlett-Packard 5890 II GLC equipped with a CARBOWAX capillary column (L: $30 \mathrm{~m}$; ID: $0.25 \mathrm{~mm}$; film thickness: $0.25 \mu \mathrm{m}$ ) and a flame ionization detector. Integration of spectra peaks and quantification of fatty acid methyl esters was accomplished by the HewlettPackard CHEM STATION software.

\section{Lipid peroxidation}

Liver tissue was assayed for lipid peroxides by the lipidconjugated diene assay. Liver lipid-conjugated dienes were determined by a modified method of Watson et al. (1984). Approximately $0.5 \mathrm{~g}$ of tissue was homogenized for $30 \mathrm{~s}$ in a Polytron in $4.5 \mathrm{ml} 0.15 \mathrm{M}-\mathrm{NaCl}$ containing 0.0008

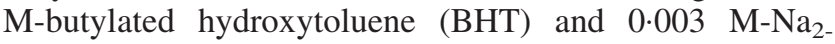
EDTA. Lipids were extracted with chloroform/methanol $(2: 1, \mathrm{v} / \mathrm{v})$ according to the method described by Folch et al. (1957). The chloroform layer was dried under a stream of $\mathrm{O}_{2}$-free $\mathrm{N}_{2}$, and the weight of the extracted lipid was 
determined. The lipid was dissolved in $2 \mathrm{ml}$ cyclohexane and absorbance was determined spectrophotometrically at $234 \mathrm{~nm}$ with cyclohexane as a blank. The lipid-conjugated diene concentration was calculated by dividing the absorbance reading by the molar absorptivity. The concentration value was expressed as $\mu \mathrm{mol} / \mathrm{mg}$ lipid.

\section{Statistical analysis}

Differences among dietary treatment groups were assessed by one-way ANOVA, using the ABstat (1993) general linear model program. The Scheffé multiple comparison method was used to differentiate among means for variables that were significantly affected by the treatments (Snedecor \& Cochran, 1980). Values are expressed as mean with their standard errors. Correlation coefficients were determined using Pearson's product moment correlation matrix (Snedecor \& Cochran, 1980).

\section{Results \\ Liver}

After 12 weeks of treatment, hepatocellular hypertrophy, manifested as enlargement of the individual hepatocytes, was observed in six of ten animals fed diets containing $20000 \mu \mathrm{g} \mathrm{Fe} / \mathrm{g}$. The enlarged hepatocytes, located predominantly in the periportal region of the liver lobules, were characterized by an increased amount of cytoplasm in relation to the nucleus and a large amount of granular cytoplasmic Fe. In the control group, a small amount of Fe was observed only in macrophages found in the liver sinuses. As shown in Table 2, the increase in liver non-haem Fe concentration was significantly greater in those groups of rats fed diets containing 3500 and $20000 \mu \mathrm{g} \mathrm{Fe} / \mathrm{g}$. The increase in non-haem $\mathrm{Fe}$ was also paralleled by an increase in the ratio of liver weight:body weight in animals receiving Fe-fortified diets.

As the amount of $\mathrm{Fe}$ in the diet increased, liver conjugated dienes increased from 0.019 to $0.039 \mu \mathrm{mol} / \mathrm{mg}$ lipid (Table 2). Total liver non-haem Fe was directly correlated with conjugated dienes $(r$ 0.90).

\section{Serum iron and total iron-binding capacity}

Serum $\mathrm{Fe}$ and TIBC of Fe-overloaded rats were not significantly different from those of control animals (Table 2 ). The animals receiving the Fe-deficient diet, however, had significantly decreased serum Fe levels and increased TIBC levels when compared with the control animals.

\section{Serum lipids}

Serum cholesterol increased from 2.0 for control animals to $5 \cdot 2 \mathrm{mmol} / \mathrm{l}$ in animals fed the highest dose of $\mathrm{Fe}$ (Table 3 ). As the Fe dose increased there was an increase in serum cholesterol with the exception of the Fe-deficient group. Serum triacylglycerol levels did not increase with Fe dose and the only statistically significant difference found was between the $\mathrm{Fe}$-deficient and $3500 \mu \mathrm{g} \mathrm{Fe} / \mathrm{g}$ groups (Table 3 ).

Serum phospholipid fatty acids generally increased with 
Fe dose and saturated, unsaturated and total phospholipid fatty acids were all significantly elevated $(P<0 \cdot 001)$ in the group of animals fed $20000 \mu \mathrm{g} \mathrm{Fe} / \mathrm{g}$ in comparison with controls. In all of the groups with the exception of the $20000 \mu \mathrm{g} \mathrm{Fe} / \mathrm{g}$ group the ratio of the saturated to unsaturated phospholipid fatty acids increased from 1.2 to $1 \cdot 7$, with increasing Fe dose (Table 3).

Serum free fatty acids did not increase with Fe dose. Saturated, unsaturated and total free fatty acids were not significantly different among dietary Fe doses (Table 3).

\section{Heart}

In the heart, non-haem $\mathrm{Fe}$ increased with dose, and the amount of Fe was significantly higher in animals receiving $20000 \mu \mathrm{g} \mathrm{Fe} / \mathrm{g}$ diet when compared to the control group (Table 2). The ratio of heart weight:body weight was significantly higher in animals receiving the $20000 \mu \mathrm{g} \mathrm{Fe} / \mathrm{g}$ diet. The incidence of severity of cardiomyopathy increased with higher dietary concentrations of $\mathrm{Fe}$ and was characterized by a spectrum of lesions. These included small foci of degenerated myofibres with variable numbers of mononuclear and polymorphonuclear inflammatory cells and a few fibroblasts with or without oedema, to extensive areas of degeneration or necrosis of myofibres. There were areas of fibrosis near these degenerative or necrotic lesions, as well as disruption of the ventricular or atrial walls, and thrombi formation. Seven animals, two animals on $3500 \mu \mathrm{g}$ $\mathrm{Fe} / \mathrm{g}$ and five on $20000 \mu \mathrm{g} \mathrm{Fe} / \mathrm{g}$, died before termination of the study. Five of these seven animals had heart damage, which included $\mathrm{Fe}$ in the cytoplasm of the myocardial fibres, haemorrhagic necrosis, epicardial damage and clot formation.

\section{Discussion}

In the present study, feeding rats diets supplemented with carbonyl $\mathrm{Fe}$ resulted in dose-related increases in liver nonhaem Fe and lipid peroxidation. Liver lipid peroxidation, which was measured in liver tissue by the conjugated diene assay, was highly correlated with the total hepatic non-haem Fe level ( $r$ 0.90). The liver non-haem Fe levels of $112 \mu \mathrm{g} / \mathrm{g}$ for the control rat group equates well with values obtained for normal human subjects of approximately $100 \mu \mathrm{g} / \mathrm{g}$. In patients with genetic haemochromatosis, liver biopsies show non-haem Fe levels greater than $600 \mu \mathrm{g} / \mathrm{g}$ (Whittaker et al. 1989); this would equate to the groups receiving the two highest doses with mean levels of 911 and $3501 \mu \mathrm{g} / \mathrm{g}$. There was also an enlargement of the liver and heart with increasing $\mathrm{Fe}$ dose when comparing the organ weights to body weight. In heart tissue of rats fed diets containing 3500 and $20000 \mu \mathrm{g} \mathrm{Fe} / \mathrm{g}$ morphological changes characteristic of cardiomyopathy were observed. As dietary intake of $\mathrm{Fe}$ increased, there was a dose-related increase in heart nonhaem $\mathrm{Fe}$, and in animals with heart damage, there was inflammation and myocyte degeneration with haemosiderin in interstitial macrophages or in myocardial fibres. Histopathology indicated hepatocellular haemosiderosis and cellular necrosis in the heart; when these were coupled with lipid peroxidation in the liver, this suggested 
that oxidative stress was involved in the pathogenesis of the lesions.

A possible mechanism for tissue damage from chronic $\mathrm{Fe}$ overload may be the effect of free radical formation and lipid peroxidation. Whittaker et al. (1992) previously reported that liver lipid peroxides were significantly increased in Fe-overloaded rats. In the human body $\mathrm{Fe}$ turnover appears to be limited to about $10 \%$ per year or a daily excretion of $0.03 \%$ (Finch, 1959). By comparison, the body $\mathrm{Fe}$ turnover in the rat is $0.38 \%$ per day (Finch et al. 1978), which makes a deleterious finding in the rat more significant.

In haemochromatosis patients, congestive heart failure is a common complication and cause of death (Powell \& Isselbacher, 1987). Olson et al. (1987) reported that hearts obtained at autopsy from men with genetic haemochromatosis had markedly increased amounts of $\mathrm{Fe}$ as compared to controls. The stainable Fe was exclusively sarcoplasmic, indicating that cardiac involvement in genetic haemochromatosis represents a storage disease and not an infiltrative process.

In the present study, we also found that serum cholesterol concentration increased directly with $\mathrm{Fe}$ supplementation. Brunet et al. (1999) administered a diet with $3 \%$ carbonyl $\mathrm{Fe}$ to rats for 12 weeks and found a significant increase in cholesterol and triglycerides when compared with control animals. They also assessed key enzymes for cholesterol homeostasis and found a reduction in 3-hydroxy-3-methylglutaryl-Co A reductase and cholesterol $7 \alpha$-hydroxylase, and an enhancement of acyl-Co A-cholesterol acyltransferase activity. They reported that this may have been a result of marked membrane lipid peroxidation that brings about fluidity drop in microsomes of Fe-loaded rats. Dabbagh et al. (1994) also found that Fe overload in male Sprague-Dawley rats caused a significant increase in plasma cholesterol and moderately increased lipid peroxidation in the liver. The increase in plasma cholesterol was explained by a decrease in antioxidant levels in plasma and liver. Whittaker et al. (1996b) examined the ability of dietary antioxidants to reduce lipid peroxidation by $\mathrm{Fe}$ overload. Lipid peroxidation was significantly reduced $(P<0.001)$ in all animals fed the antioxidants. Total serum cholesterol levels in two groups of animals receiving the diets containing high $\mathrm{Fe}(1 \%)$ with $\beta$-carotene alone or high Fe with $\beta$-carotene plus $\alpha$-tocopherol were significantly reduced $(P<0.001)$ to the level of the control group.

Foretz et al. (1999) examined the effects of polyunsaturated fatty acids on the expression of lipogenic genes, fatty acid synthase and spot-14-protein, in cultured rat hepatocytes. They reported that the inhibitory effect of polyunsaturated fatty acids on lipogenesis-related genes linked to a cytotoxic effect due to lipid peroxidation.

From the data of this study and the others cited, it appears that lipid peroxidation and cytotoxicity are important in altering lipid metabolism, possibly by their effect on lipogenesis-related genes (Foretz et al. 1999) and key enzymes for cholesterol homeostasis (Brunet et al. 1999). Damage to cellular lipids may result in structural alterations, such as membrane fluidity and fragility, and in functional alterations. Oxidative changes in lipoproteins may result in altered lipoprotein-receptor interaction in extrahepatic target cells, leading to changes in serum lipid profiles. The oxidative change in the liver may have resulted in alterations in sterol synthesis, leading to increased serum cholesterol levels with concurrent increases in serum phospholipids and changes in the ratios of their saturated to unsaturated fatty acids.

Further investigations are required to determine the specific mechanisms of the effects of Fe supplementation on blood lipids.

\section{References}

ABstat (1993) Abstat User Manual, Version 6.04. Parker, CO: Anderson-Bell.

Ascherio A, Walter CW, Rimm EB, Giovannucci EL \& Stampfer MJ (1994) Dietary iron intake and risk of coronary disease among men. Circulation 89, 969-974.

Baer DM, Tekawa IS \& Hurley LB (1994) Iron stores are not associated with acute myocardial infarction. Circulation 89, 2915-2918.

Brunet S, Thibault L, Delvin E, Yotov W, Bendayan M \& Levy E (1999) Dietary iron overload and induced lipid peroxidation are associated with impaired plasma lipid transport and hepatic sterol metabolism in rats. Hepatology 29, 1809-1817.

Burkitt MJ \& Mason RP (1991) Direct evidence for in vivo hydroxyl-radical generation in experimental iron overload. Proceedings of the National Academy of Sciences USA 88, 8440-8444.

Dabbagh AJ, Mannion TS, Lynch M \& Frei B (1994) The effect of iron overload on rat plasma and liver oxidant status in vivo. Biochemical Journal 300, 799-803.

Finch CA (1959) Body iron exchange in man. Journal of Clinical Investigation 38, 392-396.

Finch CA, Ragan HA, Dyer IA \& Cook JD (1978) Body iron loss in animals. Proceedings of the Society for Experimental Biology and Medicine 159, 335-338.

Folch J, Lees M \& Sloane Stanley GH (1957) A simple method for the isolation and purification of total lipids from animal tissues. Journal of Biological Chemistry 226, 497-509.

Foretz M, Foufelle F \& Ferré P (1999) Polyunsaturated fatty acids inhibit fatty acid synthase and spot-14-protein gene expression in cultured rat hepatocytes by a peroxidative mechanism. Biochemistry Journal 341, 371-376.

Kiechl S, Aichner F, Gerstenbrand F, Egger G, Mair A, Rungger G, Spogler F, Jarosch E, Oberhollenzer F \& Willeit J (1994) Body iron stores and presence of carotid atherosclerosis: results from the Bruneck study. Arteriosclerosis and Thrombosis 14, $1625-1630$.

Kiechl S, Willeit J, Egger G, Poewe W \& Oberhollenzer F (1997) Body iron stores and the risk of carotid atherosclerosis: prospective results from the Bruneck study. Circulation 96, 3300-3307.

Klipstein-Grobusch K, Koster JF, Grobbee DE, Lindemans J, Boeing H, Hofman A \& Witteman JCM (1999) Serum ferritin and risk of myocardial infarction in the elderly: the Rotterdam study. American Journal of Clinical Nutrition 69, 1231-1236.

Lauffer RB (1991) Iron stores and the international variation in mortality from coronary artery disease. Medical Hypotheses 1991, 96-102.

Liao Y, Cooper RS \& McGee DL (1994) Iron status and coronary heart disease: negative findings from NHANES 1 epidemiologic follow-up study. American Journal of Epidemiology 139, $704-712$.

Luna LG (1968) Manual of Histologic Staining Methods of the 
Armed Forces Institute of Pathology, 3rd ed. New York: McGraw-Hill.

Lynch SM \& Frei B (1993) Mechanisms of copper-and irondependent oxidative modification of human low density lipoprotein. Journal of Lipid Research 34, 1745-1753.

Magnusson MK, Sigfusson N, Sigvaldason H, Johannesson GM, Magnusson S \& Thorgeirsson G (1994) Low iron-binding capacity as a risk factor for myocardial infarction. Circulation 89, $102-108$.

Morrison WR \& Smith LM (1964) Preparation of fatty acid methyl esters and dimethylacetals from lipids with boron trifluoridemethanol. Journal of Lipid Research 5, 600-608.

Olson LJ, Edwards WD, McCall JT, Ilstrup DM \& Gersh BJ (1987) Cardiac iron deposition in idiopathic hemochromatosis: Histologic and analytic assessment of 14 hearts from autopsy. Journal of the American College of Cardiology 10, 1239-1243.

Powell LW \& Isselbacher KJ (1987) Hemochromatosis. In Harrison's Principles of Internal Medicine, 11th ed., pp. 1632-1635 [E Braunwald, KJ Isselbacher, RG Peterdorf, JD Wilson, JB Martin and AS Fauci, editors]. New York: McGrawHill.

Rasmussen ML, Folsom AR, Catellier DJ, Tsai MY, Garg U \& Eckfeldt JH (2001) A prospective study of coronary heart disease and the hemochromatosis gene (HFE) C282Y mutation: the Atherosclerosis Risk in Communities (ARIC) study. Atherosclerosis 154, 739-746.

Reunanen A, Takkunen H, Knekt P, Seppanen R \& Aromaa A (1995) Body iron stores, dietary iron intake and coronary heart disease mortality. Journal of Internal Medicine 238, 223-230.

Salonen JT, Nyyssönen K, Kirpela H, Tuomilehto J, Seppänen R \& Salonen R (1992) High stored iron levels are associated with excess risk of myocardial infarction in Eastern Finnish men. Circulation 86, 803-811.

Schwartz CJ, Valente AJ, Sprague EA, Kelley JL \& Nerem RM (1991) The pathogenesis of atherosclerosis: An overview. Clinical Cardiology 14, 1-16.

Sempos CT, Looker AC, Gillum RF \& Makuc DM (1994) Body iron stores and the risk of coronary heart disease. New England Journal of Medicine 330, 1119-1124.
Smith C, Mitchinson MJ, Aruoma OI \& Halliwell B (1992) Stimulation of lipid peroxidation and hydroxyl-radical generation by the contents of human atherosclerotic lesions. Biochemical Journal 286, 901-905.

Snedecor GW \& Cochran WG (1980) Statistical Methods, 7th ed., pp. 175-193, 215-237. Ames, IA: The Iowa State University Press.

Stevens RG, Graubard BI, Micozzi MS, Neriishi K \& Blumberg BS (1994) Moderate elevation of body iron level and increased risk of cancer occurrence and death. International Journal of Cancer 56, 364-369.

Thompson SW \& Hunt RD (1966) Selected Histochemical and Histopathological Methods. Springfield, IL: Charles C. Thomas.

Watson BD, Busto R, Goldberg WJ, Santiso M, Yoshida S \& Ginsberg MD (1984) Lipid peroxidation in vivo induced by reversible global ischemia in rat brain. Journal of Neurochemistry 42, 268-274.

Whittaker P, Hines FA, Robl MG \& Dunkel VC (1996a) Histopathological evaluation of liver, pancreas, spleen, and heart from iron-overloaded Sprague-Dawley rats. Toxicologic Pathology 24, 558-563.

Whittaker P, Skikne BS, Covell AM, Flowers C, Cooke A, Lynch SR \& Cook JD (1989) Duodenal iron proteins in idiopathic hemochromatosis. Journal of Clinical Investigation 83, $261-267$.

Whittaker P, Wamer W \& Calvert RJ (1992) Effect of chronic iron overload on iron status, lipid peroxidation, cell proliferation, and DNA damage. Journal of Trace Element and Experimental Medicine 5, 227-236.

Whittaker P, Wamer WG, Chanderbhan RF \& Dunkel VC (1996b) Effects of $\alpha$-tocopherol and $\beta$-carotene on hepatic lipid peroxidation and blood lipids in rats with dietary iron overload. Nutrition and Cancer 25, 119-128.

Williams RE, Zweier JL \& Flaherty JT (1991) Treatment with deferoxamine during ischemia improves functional and metabolic recovery and reduces reperfusion-induced oxygen radical generation in rabbit hearts. Circulation 83, 1006-1014.

Witztum JL (1994) The oxidation hypothesis of atherosclerosis. Lancet 344, 793-795. 